\title{
Kiss János: Az együttérzés tanítása, avagy a gyülöletet (magától) senki nem hagyja el
}

\author{
Néhány gondolat Elliot Aronson Columbine után c. könyvéröl
}

Egy olyan szerző munkájáról beszélünk, aki az utóbbi fél évszázad megkerülhetetlen gondolkodója a szociálpszichológiában. Akinek leghíresebb könyve, A társas lény, éppen az idén lesz negyven éve, hogy megjelent Magyarországon, $\mathrm{s}$ tett szert páratlan és töretlen népszerüségre, a magyar (s szerintem általában a) tudományos könyvkiadás és az olvasók igaz örömére, s amelyen a pszichológusok generációi nőttek fel, szerte a világon. Egy olyan tudós munkájáról van szó, akire nem lehet nem odafigyelni, már csak azért sem, mert tudományos témáinak, s így müveinek zömét a mindennapi életünk egy-egy fontos eseménye inspirálja. A 60-as években nagy port felvert Kitty Genovese-eset motiválta kísérletsorozata nagyon közismert lett, bár éppen a napjainkban zajló illúzióromboló, a szociálpszichológiai kutatások manipulációit leleplező cikkek erről az esetről is írnak, igaz, nem a pszichológusok, hanem az esetet torzan tálaló korabeli média felelősségét firtatva. A tudomány tevékenysége során is, elsősorban a gyakorlatot próbálja értelmezhetővé tenni az elmélet által, s nem teóriákat próbál kitalálni a gyakorlat számára. Kísérletező ember, aki az élet mindennapi színterein próbálkozik, és mindezt lebilincselően egyszerü, elbűvölően szórakoztató, ugyanakkor elgondolkodtatóan mély formában teszi. Azok közé tartozik, akik ,élőben” is olyanok, mint könyveikben. Teljesen jellemzö élménye volt jelen sorok írójának Aronsonnal kapcsolatban, hogy a 80-as évek legelején, egy általa tartott szentendrei workshopon, a résztvevők mindig hamarabb nevettek a poénjain, mint ahogy jött a fordítás, pedig akkoriban (legalábbis én) igen kevéssé bírtuk az angol nyelvet, de annyira világos és érthető volt a közlő szándéka, hogy „átjött” tolmács nélkül is. Feltétlenül érdemes elmondani, hogy Erős Ferenc értő fordítása (aki lektora is a recenzióban szereplö könyvnek) nagyban hozzájárult A társas lény magyarországi diadalútjához.

Nincs ez másképp ezzel a munkájával sem, jól tagolt és világosan megfogalmazott gondolatokból álló, kiváló fordításban megjelent könyvről van szó. De mi adja egy 2000-ben megjelent mủ aktualitását csaknem húsz évvel később? Napjaink terrorfenyegetettsége újból a társadalmi érdeklődés homlokterébe helyezte az erőszakos cselekményeket. Az iskolai támadások elkövetői természetesen teljesen más úton jutnak el a tragikus végkifejletig, mint a politikai terroristák, csupán a véres következmény és az azt követő (vágyott) médiahírnév a közös. Már a könyv elején nyilvánvalóvá teszi Aronson, hogy a columbine-i tragikus események legfőbb oka nem az agressziót generáló, öldöklést és verekedést szimuláló számítógépes játékok, de nem is a liberális és könnyen kijátszható amerikai fegyvertartási törvények, bár nyilvánvalóan károsan befolyásolják a fiatalokat és megkönnyítik számukra az ilyen jellegü cselekmények tervezését és kivitelezését, hanem a kirekesztés, az elkülönítés. Pontosabban ezek következményeként, az elutasítás miatti frusztráció generálta, dühvé kumulálódó feszültség. Ez pedig nem pusztán napjaink jelensége Amerikában, hiszen pl. az etnikai alapon történő teljesen elkülönített oktatás az 50-es évek elején szünt meg az USAban, de a megkülönböztetés gerjesztette etnikai feszültségek időről időre fellángolnak a világban, pár napja Nantes-ban történt ilyesmi, de Magyarországon sem ismeretlenek az etnikai különbségekből eredeztethető feszültségek, melyet ráadásul napjaink „migráns” 
problémájának politikai interpretálása tovább fokoz. Elmondja rögtön Aronson, hogy nem kell akkora különbség (ha úgy tetszik másság) az elkülönüléshez, a kirekesztettséghez, mint pl. a bőrszín vagy bármely rasszjegy. Sőt látható jele sincs feltétlenül, hiszen elegendő pusztán az, hogy máshonnan jött valaki, vagy más (vallás, eszmék, kultúra, hobbi, focicsapat stb.) értékeket preferál. Kimondja, hogy a társas elkülönítés okozta hátrányokat soha nem lehet eredményesen kompenzálni más (jogi, anyagi stb.) területen az esélyek, körülmények kiegyenlítésével.

Természetesen a megoldásra is kitér Aronson és ajánlásokat tesz erre nézve. Ennek kapcsán „mellékesen” két nagy fontos következtetést is megoszt velünk. Az egyik a megoldásra szánt intézkedések természete kapcsán, nevezetesen, hogy a legjobb szándékkal is meghozott intézkedések egy (jó) része csupán a felelősséget kereső, ahogyan szerzőnk fogalmaz, „kárhoztató” önvédelmi célokat szolgáló, tartós valódi változásokat nem nagyon hozó eszközök. Ugyanis csak a ,gyökerekig hatoló” elképzelések azok, amelyek nemcsak felszínen, mintegy tünetként jelentkező dolgokat kezelik, hanem kauzális jellegúek, azaz a kiváltó okot próbálják kezelni. A másik nagyon fontos megállapítása ezzel kapcsolatosan az, hogy pl. a szociálpszichológia-kutatók szinte minden ehhez szükséges ismeretet feltártak már, de ezek mégsem közismertek, nem kapnak akkora publicitást, mint mondjuk a gyógyszeripari kutatások eredményei, valószínúleg a várható közvetlenebb anyagi következmény és a könnyebb hatásos (lájkvadász) tálalás miatt sokkal több emberhez jut el, mint a jobbára csak tudományos folyóiratokban és könyvekben megjelenő „hétköznapi” pszichológiai eredmények. Lám, most is a Zimbardo nevével jelzett „manipulációs botrányt” leleplező cikkek jelennek meg és kapnak nagyobb figyelmet, mint a máig érvényes következtetéseket hordozó többi szociálpszichológiai kísérlet. Az érzelmi intelligencia jelentőségét állítja középpontba a probléma megértésének és kezelésének alapjaként. A közgondolkodásban sokkal nagyobb jelentőséget tulajdonítanak a (mondjuk így) értelmi intelligenciának, az „IQ”nak, semmint az érzelmekkel való hatékony bánás képességének, az „EQ”-nak, holott utóbbi, még az iskolai tanulmányi teljesítmények hátterében is inkább feltételezhető, mint az előbbi. Azt ajánlja Aronson, hogy az iskolákban számoljanak le végre azzal, hogy a tanórákon a tantárgyak tudományos és gyakorlati tartalmainak oktatása az elsődleges, és a diákok belső (érzelmi, erkölcsi stb.) nevelése ettől elvonja az időt és a figyelmet, hanem éppen ellenkezőleg, erősítheti annak hatékonyságát. Olyan jól ismert jelenségek, mint az együttérzés, együttmüködés, empátia stb. erősítése, fejlesztése a legkönnyebben járható út, melyről a tudomány viszonylag régóta és elég sokat tud, de a fentebb említett okok miatt még nem egészen váltak közismertté, még talán a pedagógusképzés képviselői számára sem. Pedig pl. az általa (és kollégái által) kidolgozott és fényesen bevált ún. „mozaikmódszer” már legalább 50 éves múltra tekint vissza, sok ismert publikációban megjelent, sőt pl. Magyarországon is van „mozaikegyesület”. Az együttérzést tanítani lehet és kell, hiszen a gyülöletet (magától) senki nem hagyja el, ahogy a könyv eredeti címe is mondja. Ezek valóban tanulható és tanítható, fejleszthető dolgok, amelyhez ráadásul nagyon sok pénzre sincsen szükség.

Meg még valamire. Némi aktuálpolitikai áthallása is lehet annak a fejezet(al)címnek, hogy „...nem (csak) az számít, amit mondunk, hanem az (is), amit teszünk...” A zárójelbe tett dolgok a recenzens szubjektív kiegészítései... Szóval nem a szavak és tettek közötti diszkrepancia növelésére biztat bennünket Aronson, hanem az okos, bölcs és szép szavak mellett, a személyes példamutatásra. Bennünket olvasókat, nemcsak a tanárokat, hanem a társadalom minden tagját. Ezzel az üzenettel zárul a könyv, mely majdnem 20 év után is 
DOI: $10.29376 /$ parbeszed/2018/3/10

aktuális és tud újat adni, és amelyet minden írástudó, a közösségért felelősséget érző ember kezébe jó szívvel ajánlok. 